\title{
Pituitary deficiency due to Rathke\&apos;s cleft cysts
}

INSERM

\section{Source}

INSERM. (1999). Orphanet: an online rare disease and orphan drug data base. Pituitary deficiency due to Rathke's cleft cysts. ORPHA:91350

Pituitary deficiency due to Rathke's cleft cysts is a rare, acquired pituitary hormone deficiency characterized by combination of headache, visual field defects that correlate with cyst size, and pituitary dysfunction. Most frequent hormonal manifestations are hypogonadism with amenorrhea/impotence or low libido and galactorrhea. 